\title{
Environmental Quality Evaluation of Lakes in the Rio Grande do Sul Coastal Plain
}

\author{
Catarina da Silva Pedrozo ${ }^{1}$ and Odete $\operatorname{Rocha}^{2} *$ \\ ${ }^{l}$ Departamento de Ecologia; Universidade Federal do Rio Grande do Sul; Av. Bento Gonçalves, 9500; prédio \\ 43422; 91540-000; Porto Alegre - RS - Brasil. ${ }^{2}$ Departamento de Ecologia e Biologia Evolutiva; Universidade \\ Federal de São Carlos; Via Washington Luiz; km 235; C. P. 676; 13560-905; São Carlos - SP - Brasil.
}

\begin{abstract}
The purpose of the present work was to evaluate the environmental quality of Marcelino, Pinguela, Peixoto, Palmital, Malvas and Do Passo lakes, interconnected by canals and located in the district of Osório, RS. In this context, 29 physical and chemical variables were analyzed with sampling carried out in January, May, July and October 1997 to verify the environmental quality of the system and the existence of a gradient of quality. Canonical Analysis was applied to the data of all environmental variables measured, and showed that the lakes had different characteristics as a consequence of the organic pollution received. Marcelino lake received continuous input of organic matter from the sewage treatment works in the town of Osório, whereas Peixoto, Pinguela, Palmital, Malvas and Do Passo lakes resembled other water bodies described in the region, not showing, so far, signs of degradation caused by the input of effluents. Principal Component Analysis selected environmental element were directly linked to organic pollution, that reflected sequential non-recent effects of contamination.
\end{abstract}

Key words: Castal lakes, water quality, environmental variables, limnological characteristics

\section{INTRODUCTION}

There are around one hundred lakes along the Coastal Plain of Rio Grande do Sul State in south Brazil, all separated from the ocean by barriers sculpted by fluvial, aeolian, marine and human processes (Tomazelli and Willwock, 1991). These bodies of water have a great influence over the restinga coastal vegetation system (Schäfer, 1988) and their morphological and chemical nature depends on age, distance from the coastline and the influence of sedimentary loads of aeolian and/or fluvial origin, brackish waters and human action (Schwarzbold, 1982; Schwarzbold and Schäfer, 1984; Fonseca, 1989; Tomazelli and Willwock, 1991). The development of several towns along the northern part of the coast of Rio Grande do Sul has led to the occupation and modification of areas surrounding the lakes of the River Tramandaí Hydrographic Basin. With the input of domestic waste and efluent from rice farms and other agricultural activities, this system has been strongly affected by human activities. The coastal region is an important tourist resource for the State, hence the rising level of economic activity in the coastal towns during summer. With the constant growth of these urban zones, the lakes, which are tourist attractions, along with the littoral zone, have been increasingly exploited for the practice of aquatic sports and construction of summer residences.

\footnotetext{
${ }^{*}$ Author for correspondence
} 
Thus, the purpose of the present work was to evaluate the environmental quality of six lakes starting with the hypothesis that a gradient of quality exists among these lakes.

\section{Study Area}

The Coastal Plain of Rio Grande do Sul state is $640 \mathrm{~km}$ long, from Torres in the North to La Coronilha, Uruguay, in the South. This area lies between $20^{\circ} 12^{\prime}$ and $33^{\circ} 48^{\prime} \mathrm{S}$ and $49^{\circ} 40^{\prime}$ and $53^{\circ} 30^{\prime} \mathrm{W}$, in Brazilian territory. A sequence of longitudinal formations, parallel to the coast, runs up to Serra Geral mountains, characterizing North portion of the coastal region of Rio Grande do Sul littoral. At the land-sea interface, there is a typical sedimentar coastal plain formed by primary, secundary and terciary dunes, followed by a strip of lagoons. This is followed by Maquine and Três Forquilhas Valleys until the mountain slopes, over which is found an Atlantic Forest permanent preservation nucleum, considered a Biosphere Reserve. The regional economy is based on the agriculture, furniture industry and tourism activities (Fepam, 2000). Apart from the larger lakes, the area has a considerable number of smaller water bodies, some located along the coast and some inland. The climate of the region was classified by Hasenack and Ferraro (1989) as type Cfa (Köppen's classification) or humid subtropical, with rain all year round, and a hot summer and cold winter. Temperatures in the warmest month are above $22^{\circ} \mathrm{C}$ and in the coldest month vary between -3 and $18^{\circ} \mathrm{C}$.

Predominant direction of winds in one yearly cycle, from October 1997 to September 1998, was as follows: $2.04 \%$ North, $43.46 \%$ Northeast, $8.53 \%$ East, $11.03 \%$ Southeast, $4.36 \%$ South, $10.66 \%$ Southwest, $6.39 \%$ West and $13.53 \%$ Northwest. The data revealed a predominance of northeasterly winds in the region a result supported by several authors (Würdig 1984, Hasenack and Ferraro, 1989, Tomazelli and Willwock, 1991, Tabajara 1994, Cardoso, 2001 and Cardoso and Marques, 2004). Water temperature varied in accordance with a regional climate pattern (summer average: $27.0^{\circ} \mathrm{C}$ in January and winter average, $11.3^{\circ} \mathrm{C}$ in July), repeating a similar temperature pattern at all sampling stations. Mean annual precipitation was around $1300 \mathrm{~mm}$ (Moreno, 1961). According to Fonseca (1989), relative humidity was slightly lower next to the inland plateau $(76-81 \%$ in
Osório) than next to the sea ( $80-86 \%$ in Imbé). Northeast winds predominate, with yearly average speeds of $5.4 \mathrm{~m} / \mathrm{s}$ in Osório and $6.0 \mathrm{~m} / \mathrm{s}$ in Imbé.

The six lakes included in this study were classified by Schwarzbold (1982) as belonging to the Tramandaí System. According to Machado (2001), the morphometric descriptors of these water bodies were: Marcelino Lake: surface area $0.43 \mathrm{~km}^{2}$, maximum depth $1.30 \mathrm{~m}$, average depth $0.74 \mathrm{~m}$; Peixoto Lake: surface area $2.61 \mathrm{~km}^{2}$, maximum depth $2.10 \mathrm{~m}$, average depth $1.38 \mathrm{~m}$; Pinguela-Palmital-Malvas system as named by Machado (2001): surface area $50.07 \mathrm{~km}^{2}$, maximum depth $3.80 \mathrm{~m}$, average depth $1.78 \mathrm{~m}$; Passo Lake: surface area $3.99 \mathrm{~km}^{2}$, maximum depth $4.30 \mathrm{~m}$, average depth $1.38 \mathrm{~m}$. Osório city receives a vast number of tourists in summer, considerably increasing the population and the production of domestic waste, which are released, without treatment to this date, straight into the Marcelino lake. The water flows from Marcelino Lake towards Tramandaí River.

These water bodies are interconnected by canals and located in the district of Osório city, RS, along the BR101 Road. They represent flora and fauna corridors that are important for reprodution of farming of fishes including endemic or near extinction species. Fig. 1 shows the location of the sampling stations through the lakes on the northern coast plain of Rio Grande do Sul.

\section{MATERIALS AND METHODS}

Sampling was carried out in January, May, July and October 1997 and the sampling stations were chosen in order to include different environments (margins and centre) and also taking into account the main direction of the wind - NE to SW. Two sites were chosen in Marcelino Lake (1 and 2), three in Peixoto Lake $(3,4,5)$ five in Pinguela Lake $(6,7,8,9,10)$, three in Palmital Lake $(11$, $12,13)$, three in Malvas Lake $(14,15,16)$ and three in Passo Lake $(17,18,19)$.

Physical and chemical characteristics of the water were analyzed to verify the environmental quality of the system. In all, 29 variables were measured. Samples were taken at $7.30-9.00$ and $15.00-$ 17.00 on two consecutive days. Depth, transparency and water temperature were measured in situ, with a white Secchi disk and a mercury thermometer. Conductivity and $\mathrm{pH}$ were analysed with a WTW conductivity meter LF197 
model and a WTW potentiometer pH197 model. Oxygen saturation was calculated from $\mathrm{O}_{2}$ described by Golterman et al., (1978).

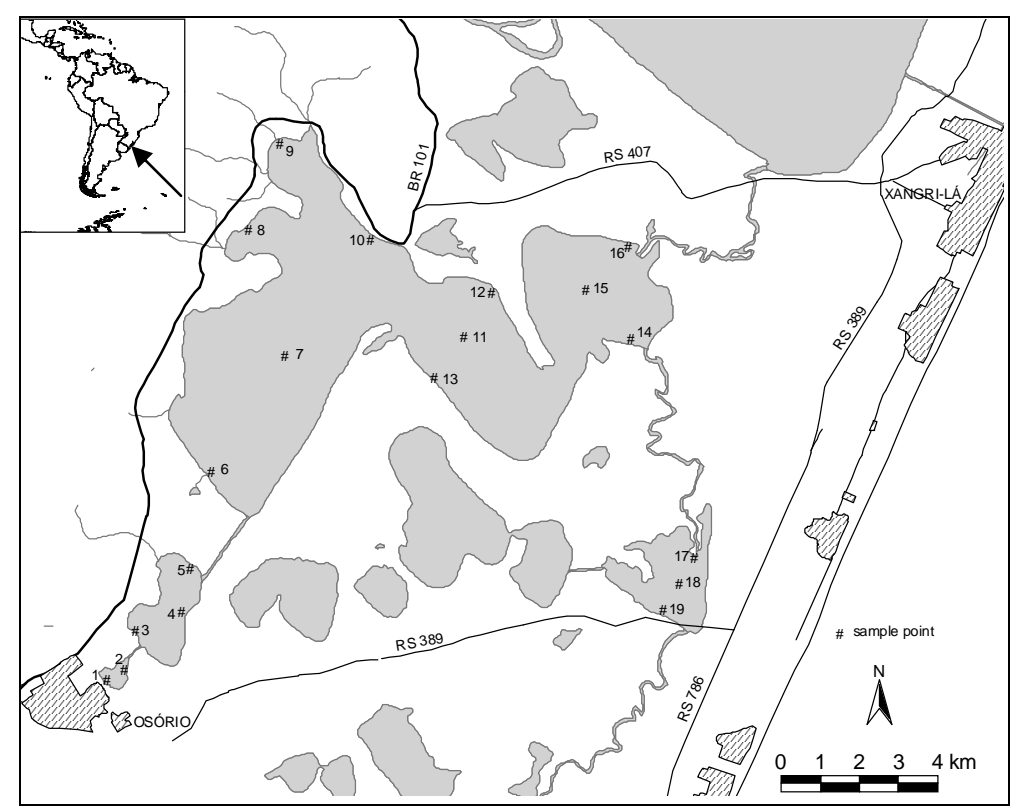

Figure 1 - Location of sampling sites. 1, 2 = Marcelino Lake; 3, 4, 5 = Peixoto Lake; 6, 7, 8, 9, 10 = Pinguela Lake; 11, 12, 13 = Palmital Lake; 14, 15, 16 = Malvas Lake; 17, 18, $19=$ Do Passo Lake. Source: Idrisi Study Centre, Centre of Ecology, UFRGS.

The methods to determine alkalinity, chlorides, hardness, sulphates, $\mathrm{BOD}_{5}, \quad \mathrm{COD}$, total phosphorus, orthophosphate, dissolved oxygen, total nitrogen, ammoniacal nitrogen, nitrate, nitrite, turbidity, calcium, potassium, magnesium, sodium, dissolved solids, organic suspended solids and inorganic suspended solids followed those of APHA (1995). Chlorophyll $a$ was estimated by spectrophotometry (Golterman et al., 1978). Rainfall and wind direction data were obtained from the $8^{\text {th }}$ Meteorology District of Rio Grande do Sul.

Principal Components Analysis (PCA; Stratigrafics Plus 6.0, 1986) was the multivariate statistical technique emplyed to detect differences between sampling sites. Comparison of sampling sites over all sampling dates was carried out with Canonical Discriminant Analysis.

\section{RESULTS AND DISCUSSION}

The environmental variables were analysed with the aim of achieving a physical and chemical evaluation of these environments. The main data are presented in Table 1.
According to Schwarzbold (1982) these lakes are shallow and vertically isothermal, as there is no thermal stratification, owing to the continuous circulation of the whole water body caused by the wind.

At all sampling sites, $\mathrm{pH}$ was near neutral, with occasional alkaline values. The highest value was found at site 2 in spring (8.02) and the lowest at 19 (6.67), also in spring. All $\mathrm{pH}$ values registered in the Coastal Lakes of the Tramandaí-Osório Region, according to Fonseca (1989), revealed near neutral average values. The highest values found in spring, especially in Marcelino lake, were probably a consequence of increased photosynthetic activity, since high chlorophyll $a$ values were also registered at the same time and sampling sites.

The lowest average value for turbidity was found in summer (54.4 NTU) and the highest in winter (147 NTU). A rise in turbidity values was detected from lakes Pinguela-Palmital to Malvas, followed by a fall in Passo lake. During the period of study, turbidity could not be associated with increased phytoplanktonic activity. Rather, it was a consequence of a high concentration of suspended 
inorganic matter, caused by the resuspension of sediments due to strong winds.

Table 1- Values of main physical and chemical variables measured in a series of interconnected lakes in the Northern coast of Rio Grande do Sul.

\begin{tabular}{|c|c|c|c|c|c|c|c|c|c|c|c|c|c|c|c|c|c|c|c|}
\hline \multirow[t]{2}{*}{ a) January 1997} & \multicolumn{15}{|c|}{ Sampling Sites } & \multirow[b]{2}{*}{16} & \multirow[b]{2}{*}{17} & \multirow[b]{2}{*}{18} & \multirow[b]{2}{*}{19} \\
\hline & 1 & 2 & 3 & 4 & 5 & 6 & 7 & 8 & 9 & 10 & 11 & 12 & 13 & 14 & 15 & & & & \\
\hline Depth $(\mathrm{m})$ & 1.11 & 1.35 & 0.91 & 2.21 & 1.19 & 1.1 & 3.35 & 1.55 & 2.5 & 0.7 & 3.2 & 1.8 & 0.7 & 1.6 & 1.9 & 3.6 & 2.65 & 1.2 & 4.3 \\
\hline Conductivity $\left(\mu \mathrm{S} \mathrm{cm}^{-1}\right)$ & 158 & 164 & 103 & 87.1 & 87.1 & 65 & 63.4 & 63.4 & 71.6 & 60.7 & 58 & 58.7 & 61.7 & 54.1 & 66.6 & 54.1 & 58.1 & 59.4 & 59.4 \\
\hline Oxygen $\left(\mathrm{mg} \cdot \mathrm{L}^{-1}\right)$ & 6.40 & 6.20 & 6.80 & 6.80 & 7.00 & 7.60 & 7.20 & 6.60 & 6.80 & 7.80 & 7.90 & 7.30 & 7.30 & 7.54 & 7.74 & 7.19 & 6.99 & 6.8 & 7.51 \\
\hline $\mathrm{BOD}\left(\mathrm{mg} \cdot \mathrm{L}^{-1} \mathrm{O}_{2}\right)$ & 11.55 & 9.33 & 4.44 & 1.66 & 1.56 & 1.00 & 0.40 & 0.97 & 0.97 & 0.42 & 0.71 & 0.50 & 0.50 & 0.35 & 0.55 & 0.31 & 1.03 & 0.97 & 0.68 \\
\hline Total Nitrogen $\left(\mathrm{mgL}^{-1}\right)$ & 1.74 & 2.80 & 0.79 & 1.26 & 1.26 & 1.74 & 0.95 & 1.42 & 1.58 & 1.42 & 1.10 & 1.58 & 2.35 & 1.88 & 2.19 & 2.50 & 2.50 & 2.19 & 1.88 \\
\hline Ammoniacal Nit. $\left(\mu \mathrm{g} . \mathrm{L}^{-1}\right)$ & 844 & 421 & 117 & 36.6 & 45.7 & 42.7 & 36.6 & 45.7 & 42.7 & 68.6 & 71.7 & 70.2 & 79.3 & 76.3 & 71.7 & 33.6 & 51.8 & 54.9 & 62.5 \\
\hline Total phosphorus $\left(\mu \mathrm{gL}^{-1}\right)$ & 345 & 390 & 128 & 38.6 & 176 & 59.3 & 136 & 86.8 & 149 & 24.8 & 66.2 & 142 & 76.5 & 38.6 & 11 & 139 & 118 & 21.4 & 135 \\
\hline Chlorophyll $a\left(\mu \mathrm{gL}^{-1}\right)$ & 29.8 & 31.2 & 9.94 & 5.87 & 5.42 & 4.52 & 4.06 & 5.42 & 2.26 & 1.80 & 2.26 & 1.80 & 0.45 & 2.64 & 1.88 & 3.01 & 1.88 & 2.26 & 3.40 \\
\hline \multicolumn{20}{|l|}{ b) May 1997} \\
\hline Depth $(\mathrm{m})$ & & & 0.9 & & 1.2 & 1.2 & 3.1 & 1.0 & 2.2 & 0.7 & 2.7 & 1.6 & 0.5 & 1.2 & 1.7 & 2.0 & 1.2 & 1.3 & 3.4 \\
\hline Conductivity $\left(\mu \mathrm{S} \mathrm{cm}^{-1}\right)$ & 234 & 235 & 106 & 106 & 106 & 73.5 & 73.3 & 72.9 & 72.9 & 71.8 & 71.6 & 72.5 & 71.4 & 59 & 68.7 & 58.8 & 57.3 & 56 & 56.1 \\
\hline Oxygen $\left(\mathrm{mg} \cdot \mathrm{L}^{-1}\right)$ & 6.32 & 6.41 & 8.55 & 8.15 & 7.97 & 8.94 & 8.36 & 8.55 & 8.74 & 8.55 & 8.55 & 8.94 & 9.13 & 8.74 & 8.94 & 8.74 & 8.55 & 8.55 & 8.55 \\
\hline $\mathrm{BOD}\left(\mathrm{mg} \cdot \mathrm{L}^{-1} \mathrm{O}_{2}\right)$ & 4.14 & 3.6 & 1.75 & 2.63 & 2.63 & 2.85 & 1.97 & 2.93 & 2.03 & 1.58 & 0.9 & 1.58 & 1.13 & 1.13 & 0.23 & 1.13 & 0.67 & 0.67 & 0.90 \\
\hline Total Nitrogen $\left(\mathrm{mgL}^{-1}\right)$ & 4.54 & 5.33 & 2.19 & 2.03 & 1.72 & 2.03 & 1.88 & 1.88 & 1.56 & 1.88 & 1.41 & 1.88 & 1.41 & 1.56 & 1.72 & 1.56 & 1.56 & 1.41 & 1.72 \\
\hline Ammoniacal Nit. $\left(\mu \mathrm{g} . \mathrm{L}^{-1}\right)$ & 786.0 & 595.0 & 88.5 & 91.5 & 79.3 & 65.5 & 83.8 & 64.1 & 93.0 & 96.1 & 74.7 & 89.9 & 124.0 & 65.5 & 68.6 & 42.7 & 80.8 & 85.4 & 83.8 \\
\hline Total phosphorus $\left(\mu \mathrm{gL}^{-1}\right)$ & 573.0 & 490.0 & 128.0 & 114.0 & 135.0 & 194.0 & 176.0 & 207.0 & 132.0 & 169.0 & 128.0 & 52.4 & 76.5 & 24.8 & 166.0 & 149.0 & 31.7 & 48.9 & 118.0 \\
\hline Chlorophyll $a\left(\mu \mathrm{gL}^{-1}\right)$ & 18.10 & 14.70 & 6.03 & 2.64 & 2.63 & 7.35 & 6.21 & 5.65 & 2.26 & 2.83 & 3.39 & 3.95 & 4.52 & 5.65 & 3.39 & 8.47 & 8.47 & 5.08 & 6.21 \\
\hline \multicolumn{20}{|l|}{ c) July 1997} \\
\hline Depth $(\mathrm{m})$ & & & & & & 1.4 & 3.0 & & & & 1.1 & 1.0 & 0.5 & 1.1 & 1.8 & 2.0 & 2.4 & 1.2 & 3.6 \\
\hline Conductivity $\left(\mu \mathrm{S} \mathrm{cm}^{-1}\right)$ & 148.2 & 148.5 & 80.5 & 83.2 & 91.1 & 57.3 & 55.8 & 55.9 & 56.6 & 56.8 & 76.2 & 76.4 & 74.3 & 70.7 & 74.6 & 70.8 & 82.3 & 91.8 & 196.3 \\
\hline xygen $\left(\mathrm{mg} \cdot \mathrm{L}^{-1}\right)$ & 5.86 & 5.29 & 7.99 & 8.7 & 7.72 & 7.15 & 7.36 & 6.68 & 6.98 & 7.03 & 8.70 & 8.90 & 8.70 & 8.70 & 8.60 & 8.40 & 8.40 & 8.60 & 8.60 \\
\hline $\mathrm{BOD}\left(\mathrm{mg} \cdot \mathrm{L}^{-1} \mathrm{O}_{2}\right)$ & 3.81 & 3.35 & 1.84 & 2.66 & 1.36 & 1.21 & 1.62 & 0.93 & 1.38 & 1.82 & 2.10 & 2.70 & 2.30 & 3.10 & 2.30 & 1.70 & 2.10 & 2.10 & 3.00 \\
\hline Total Nitrogen $\left(\mathrm{mgL}^{-1}\right)$ & 4.25 & 2.35 & 2.35 & 2.22 & 2.03 & 2.03 & 2.22 & 2.03 & 1.84 & 1.66 & 1.84 & 0.78 & 0.63 & 0.63 & 0.47 & 0.47 & 0.15 & 0.15 & 0.15 \\
\hline Ammoniacal Nit. ( $\mu$ g. $\left.L^{-1}\right)$ & 817 & 798 & 163 & 182 & 160 & 175 & 178 & 174 & 175 & 196 & 178 & 156 & 210 & 186 & 162 & 137 & 149 & 160 & 104 \\
\hline Total phosphorus $\left(\mu \mathrm{gL}^{-1}\right)$ & 266 & 270 & 183 & 145 & 173 & 138 & 142 & 162 & 190 & 178 & 129 & 193 & 171 & 117 & 117 & 131 & 126 & 186 & 164 \\
\hline Chlorophyll $a\left(\mu \mathrm{gL}^{-1}\right)$ & 0.75 & 1.13 & 1.69 & 2.26 & 1.13 & 1.50 & 0.75 & 0.75 & 1.50 & 0.75 & 2.26 & 3.01 & 2.26 & 3.01 & 1.50 & n.d & 0.75 & 2.26 & 1.05 \\
\hline \multicolumn{20}{|l|}{ d) October 1997} \\
\hline Depth (m) & 1.8 & 1.4 & 1.4 & 1.6 & 1.8 & 1.4 & 4.0 & 2.2 & 2.8 & 1.6 & 3.4 & 1.8 & 1.5 & 2.2 & 2.0 & 2.7 & 1.2 & 1.8 & 2.4 \\
\hline Conductivity $\left(\mu \mathrm{S} \mathrm{cm}^{-1}\right)$ & 125 & 135 & 84 & 85.9 & 86.1 & 73.2 & 63.9 & 62.7 & 63.1 & 63.6 & 62.6 & 63.4 & 62.5 & 52 & 61.2 & 49.2 & 51.3 & 51 & 53 \\
\hline$\left(\mathrm{mg} \cdot \mathrm{L}^{-1}\right)$ & 9.04 & 9.24 & 9.24 & 8.04 & 8.64 & 7.43 & 7.83 & 7.33 & 8.04 & 8.04 & 7.64 & 7.3 & 7.83 & 8.04 & 7.83 & 7.54 & 6.43 & 7.43 & 6.83 \\
\hline $\mathrm{BOD}\left(\mathrm{mg} \cdot \mathrm{L}^{-1} \mathrm{O}_{2}\right)$ & 4.95 & 5.22 & 3.21 & 2.00 & 2.41 & 1.00 & 0.90 & 0.80 & 1.30 & 1.80 & 0.50 & 0.70 & 0.70 & 0.70 & 1.00 & 0.70 & 0.40 & 0.80 & 0.80 \\
\hline Total Nitrogen $\left(\mathrm{mgL}^{-1}\right)$ & 3.33 & 3.33 & 2.23 & 1.85 & 2.03 & 1.1 & 1.66 & 1.66 & 0.55 & 0.54 & 0.47 & 0.47 & 0.47 & 0.63 & 0.55 & 0.55 & 0.47 & 0.55 & 0.55 \\
\hline Ammoniacal Nit. ( $\mu$ g. $\left.L^{-1}\right)$ & 515 & 225 & 94.5 & 125 & 85.4 & 140 & 136 & 120 & 129 & 134 & 163 & 181 & 133 & 154 & 163 & 148 & 137 & 116 & 127 \\
\hline Total phosphorus $\left(\mu \mathrm{gL}^{-1}\right)$ & 655 & 501 & 79.9 & 170 & 139 & 156 & 128 & 125 & 66.2 & 132 & 156 & 148 & 135 & 104 & 187 & 48.9 & 86.8 & 45.5 & 152 \\
\hline Chlorophyll $a\left(\mu \mathrm{gL}^{-1}\right)$ & 35.50 & 44.10 & 13.10 & 10.10 & 8.21 & 4.85 & 2.98 & 0.37 & nd & 0.75 & 1.12 & 0.37 & 1.12 & 1.12 & 1.49 & 0.37 & 0.75 & 0.75 & 1.12 \\
\hline
\end{tabular}

The present results supported observations made by Kirk (1983), who classified the RS Coastal Lakes as optical type $\mathrm{T}$ (turbidity), where suspended matter controled light absorption. Accordind to data reported by Machado (2001), related to the effective "fetch" (water surface in contact with the wind) calculated for the coastal lakes of Northern Rio Grande do Sul, the lowest value was found in Marcelino lake, followed by Passo Lake. The highest values were observed in Pinguela, Palmital and Malvas Lakes. On the southeast bank of Peixoto Lake (sampling site 3), the fetch values was low. Due to their large surfaces of conctact with the wind, the lakes included in this study were greatly influenced by it.

Despite the strong input of suspended matter from the town of Osório into Marcelino Lake, this rapidly sedimented and only a small fraction of it was resuspended into the water column. This water body was sheltered from the action of the winds, explaing the low turbidity found here. Passo lake also received suspended materials from João Pedro Canal, linking the river Maquine, 
which ran down from the Serra Geral uplands to the lakes. However, similar to Marcelino lake, Passo lake was sheltered from wind, had a small contact surface, and, consequently, a lower effective fetch. Water transparency was higher in the summer with a average value of $38.9 \mathrm{~cm}$. The highest result for this season was found at station 3 $(70 \mathrm{~cm})$. The results showed that Marcelino and Peixoto lakes had the highest values of water transparency. In winter, the lowest values were found at stations $1,2,3,17$ and $18(10 \mathrm{~cm})$. The overall highest transparency was found in summer at 3, with an inverse trend to that shown by turbidity. Bruschi (1998) related turbidity to velocity and wind direction data, pointing out a few aspects which showed their influence on the turbidity and transparency of Marcelino and Peixoto lakes. According to Schäfer (1992), during summer 52\% of the coastal lakes in Rio Grande do Sul exhibited transparencies from 0.55 to $1.5 \mathrm{~m}$ and $81 \%$ from 0.3 to $2.0 \mathrm{~m}$. Dissolved oxygen concentration was fairly homogeneous through the system, with a small increase in its values from Peixoto lake. The lowest oxygen values were found in summer, autumn and winter at sites 1 and 2 , located next to the sewage outlet from the town of Osório. Only in spring, the values were higher than at other sampling sites, and a bloom of cyanobacteria was observed at site 3 . The decay of this bloom mighty have been one of the causes of lower dissolved oxygen at stations other than 1 and 2. It was likely that the increase in sewage input from the town of Osório in the summer influenced the concentration of oxygen, at least in Marcelino lake. Osório received a vast number of tourist in this season, considerably increasing the population and the production of domestic waste, which were released, without treatment to this date, straight into the lake. The especially high values of dissolved oxygen found in spring in Marcelino lake, in contrast the other lakes, could be related to the cyanobacterial bloom that occurred from station 3 onwards. Camargo and Niyai (1988) observed, in Curuçá Lake, an increase in the percentage of oxygen saturation at the beginning of the sunnier period.This would probably be related to the intensity of the phytoplankton photosynthetic activity.

Although Marcelino is a small and shallow water body, like the other lakes it has a high oxygenation rate mainly due to the action of the wind. These local characteristics may attenuate the noxious effects of eutrophication, at least concerning oxygen dynamics, as pointed out by Bruschi (1998). Present results also indicated a predominance of sodium over potassium, calcium and magnesium. During summer and spring, variation was low, and the sampled sites were quite homogeneous, with values lower than those found in autumn and winter. Rainfall was highest in summer and spring than in autumn and winter, which could have contributed to a higher dilution of these elements in the water. These results pointed to a greater influence of degradation of organic matter in Marcelino lake, rather than of marine sprays. As Fonseca (1991) pointed out for Emboaba lake, the coastal lakes of Rio Grande do Sul were characterized by the low quantity of electrolytes, apart from Marcelino lake where the highest cationic concentrations were found.

The highest concentrations of sulphates and chlorides were found in Marcelino and Peixoto lakes (and the lowest in the remaining water bodies). A gradient of sulphate was observed, mainly between summer and winter. In Pinguela lake, a seasonal pattern was not found among the sampling stations. This probably indicated that sulphate and other elements entered the system at Marcelino lake sewage through, since this water body was located at a considerable distance from the sea. According to Esteves (1988), sulphate content in the water is strongly influenced by the geological nature of the underlying rocks. Distance from the sea and the evolutionary stage of the system can also determine the concentration of this element. It was likely that Passo lake had higher sulphate levels in winter (when rainfall was greater and northeasterly winds stronger) because it is closer to the sea than the other lakes. Fonseca (1991) found values higher than $20 \mathrm{mg} . \mathrm{L}^{-1}$ at Emboaba lake, which was closer to the sea than other coastal lakes.

Chloride is one of the most important inorganic ions, being highly soluble and present in virtually all water bodies. Its origin is either natural, or human contamination. As with sulphate, the highest chloride concentrations were found in Marcelino and Peixoto lakes. Bruschi (1998), applying to Marcelino and Peixoto lakes an equation relating chloride concentration to distance from the sea, predicted values lower than those found in the present water analysis, which were 1.2 and $6.9 \mathrm{mg} . \mathrm{L}^{-1}$ respectively. The differences between the predicted and actual values were probably a consequence of organic pollution, since the highest values were found in 
Marcelino lake. An exception must be made from Passo lake, nearer the sea, which had the highest winter concentrations of chlorides.

Ionic composition analysis showed a water quality gradient, the concentration falling with increasing distance of the sampling sites from the main human contribution to the system, which was the sewage input at Marcelino lake. There are exceptions, such as the higher sodium, magnesium, chloride and sulphate winter concentrations in Passo lake, and potassium in Palmital lake. It was possible that in such cases the allochthonous input at these locations was also significant, with a contribution from the River Maquine, linking Quadros lake to Malvas lake through the Joao Pedro Canal. According to Tomazelli and Willwock (1991), even during the normal precipitation periods, rainfall on the rivers Maquine and Três Forquilhas catchments reached relatively high values. This could justify the results found for Passo lake in winter, along with its proximity to the sea.

Sands at the bottom of the lakes are characterized by a discontinuous deposition of fine materials $(<0.062 \mathrm{~mm})$ (Machado, 2001). This is resuspended in the water, mainly by the action of the wind. The strong influence of this factor can easily be assessed from results of organic and inorganic suspended solids. Winter was the season of highest suspended solids concentrations in Peixoto, Pinguela, Palmital, Malvas and Passo lakes, with the values increasing in this order. Suspended solid in natural waters is made up of organic debris, plankton and erosion products. Its effects on aquatic life are indirect, since it blocks light penetration, reduces dissolved oxygen and induces an increase in water temperature. Although in smaller quantities, organic suspended solids had the same pattern of variation as the inorganic solids in the lakes. In lentic water bodies with low primary production, particulate organic matter was predominantly inorganic, made up of clay (Esteves, 1988).

The results pointed to difference trends between total dissolved solids and organic and inorganic suspended solids. The highest values of total dissolved solids found in Marcelino and Peixoto lakes could have been due to the input of sewage from Osório city into Marcelino lake. It was possible to relate, however, these results indirectly to the contribution of sewage from Osório city, since a high percentage of dissolved organic matter was derived from the decomposition of organisms produced in the water itself even though they could also be brought into the systems by neighbouring tributaries. Organic and inorganic suspended solids, especially in winter, were highest in Peixoto, Pinguela, Palmital and Malvas lakes, probably due to the wind. The highest average values of nitrogen compounds, mainly ammonia and nitrites, which were related to organic contamination, were also found in winter. Alkalinity results revealed a clear gradient, higher values being found at the sites located closer to the sewage outlet from the town of Osório, and lower values at the other sites. The highest alkalinity was found at site $2\left(1.05 \mathrm{mEq} \cdot \mathrm{L}^{-1}\right)$ in autumn and the lowest at site 15 (0.15 mEq. $\left.\mathrm{L}^{-1}\right)$ in summer. The lowest seasonal average was found in spring $\left(0.296 \mathrm{mEq} . \mathrm{L}^{-1}\right)$ and the highest in autumn $(0.387$ mEq. $\left.\mathrm{L}^{-1}\right)$. According to Schäfer (1990), domestic wastes contain, in addition to organic compounds, various types of salt originating from washing and other cleaning processes apart from carbonates and sulphates. Chlorides, alkalinity and hardness are, therefore, in some cases indicators of the presence of domestic wastes.

Values of hardness were also higher at the sampling sites located close to the sewage input, being lower at the others sites. The highest value was found at $1\left(47.6 \mathrm{mg} \mathrm{L}^{-1}\right)$ and the lowest at 13 and $16\left(13.0 \mathrm{mg} \mathrm{L}^{-1}\right)$. Despite the higher values observed at 1 and 2, according to Fonseca (1991) this system could be classified as mildly hard. Water hardness reflects mainly the content of ions calcium and magnesium ions, combined with carbonates or bicarbonates, but may also be combined with sulphides and chlorides (Margalef, 1983). According to Wetzel (1975), it is also used as an indicator of water quality. Although the hardness values found classified the waters as mildly hard, Marcelino and Peixoto lakes were clearly different from the others all year round, indicationg a quality difference.

A gradient of higher values in Marcelino lake was evident at all times when results of electrical conductivity were analysed. The highest values $\left(234.0 \mu \mathrm{S} . \mathrm{cm}^{-1}\right.$ and $\left.235.0 \mu \mathrm{S} . \mathrm{cm}^{-1}\right)$ were recorded at 1 and 2 in autumn, when the highest mean conductivity was found $\left(90.6 \mu \mathrm{S} . \mathrm{cm}^{-1}\right)$. The single exception occured in winter at 19, where the highest value of all was found $\left(200 \mu \mathrm{S} . \mathrm{cm}^{-1}\right)$. Lower conductivity values and also a lower average was observed in spring. The falling values (except in winter) of this variable, going from 
Marcelino and Peixoto to Pinguela, Palmital, Malvas and Passo lakes, showed that in the first lake, the increased availability of ions was due to decomposition processes as well as sewage input, while in the remaining lakes the metabolic processes attenuated these contributions, characterizing an efficient environment in terms of purification of the system. Other environmental variables, which also demonstrated differences between Marcelino lake and the remaining systems, were chemical oxygen demand (COD) and biochemical oxygen demand $\left(\mathrm{BOD}_{5}\right)$. Similarly to conductivity, COD evidenced a gradient of improving quality at increasing distances from Marcelino lake. The highest values for the whole year, except site 11 in winter, were found at 1 and 2 sites. Seasonally, the highest mean value of COD was found in autumn (28.8 mg. $\mathrm{L}^{-1}$ ) and the lowest value of $\mathrm{BOD}_{5}$ was found in winter $\left(2.17 \mathrm{mg} \cdot \mathrm{L}^{-1}\right)$. There was usually a strong correlation between the oxidable organic content and the biodegradable portion of these compounds in domestic wastes. The distinction between Marcelino and the remaining lakes regarding organic pollution was made clear by the summer BOD results and although in other seasons this difference was less evident, it was still verifiable. Bruschi (1998) suggested that in Peixoto lake the effects of the discharges into Marcelino lake were attenuated. It was possible that the other lakes in the system had the same ability to purify organic matter. High BOD values occurred in Marcelino lake due to the allochthonous input of organic matter. These values then decreased down the dilution gradient, from one lake to the next. COD results, on the other hand, showed a different pattern, since its values decreased less clearly than BOD. Such spatial differences were accredited to the presence of aquatic macrophytes, soil drainage and also to the neighbouring wetlands, along the gradient.

Apart from summer, the variability between sampling sites was low, total nitrogen varied greatly between sites. There was again a gradient, decreasing from Marcelino towards Passo lake. The highest mean values were found in autumn (2.06 mg. $\left.\mathrm{L}^{-1}\right)$ and the lowest in spring (1.21 mg.L $\left.{ }^{1}\right)$. Results from nitrogen and phosphorus compounds showed, similar to other variables mentioned above that there were evident differences between Marcelino lake and the remaining water bodies.
The total amount of nitrogen, in both organic and inorganic forms, remained relatively constant. The variations were related to the different forms and the metabolic value of nitrogen in the water. The ammonical nitrogen probably entered the system at higher concentrations in summer, but was rapidly assimilated by microrganisms and plants, forming organic nitrogen. In winter, when metabolic processes were slower due to the low development of the plant life and the accumulation of degradation products, the concentrations of ammoniacal nitrogen were considerably higher. Similar situations were registered by Fonseca (1991) at Emboaba lake.

The much higher nitrites levels at 1 and 2 than at the remaining sites was evident all year round. Thus, site 1 in winter had the highest value (62.5 $\left.\mu \mathrm{g} . \mathrm{L}^{-1}\right)$, while in spring, at 9, 10, 11, 12 and 13 , nitrite was not found. In well-oxygenated waters nitrite was found in very low concentrations, while in anaerobic environments, such as hypolimnium of eutrophic lakes, it was in high concentrations. Nitrite is common in polluted water, in the first organic matter mineralization zones. Observations in tropical climates have shown that the effects of heavy pollution disappear quickly, due to the intensity of the decomposition and mineralization processes at high temperatures (Kleerekoper, 1990). This seemed to be a common pattern in these aquatic systems, since in Marcelino lake, the recipient of sewage, there were high nitrite concentrations, as opposed to the remaining lakes, where it was virtually absent.

The lowest mean nitrate values were found in summer $\left(0.07 \mathrm{mg} . \mathrm{L}^{-1}\right)$ and the highest in winter $\left(0.19 \mathrm{mg} . \mathrm{L}^{-1}\right)$, and the relative variability among all sampling sites was high. In shallow tropical lakes, concentrations of nitrate and nitrite were usually linked to production and decomposition of organic matter. All ammonia resulting from organic matter degradation was normally oxidised to nitrate, depending only on oxygen availability and assimilation by algae (Wetzel, 1975). Considering the low nitrate concentrations found here, it was to be expected that the predominating nitrogen forms were reduced to ammonium, confirming the reducing conditions in these lakes, especially in Marcelino lake.

Similar to the other forms of nitrogen, the highest concentrations of ammoniacal nitrogen were found at 1 and 2, with lower and nearly constant values at all other sites. The highest values of ammoniacal nitrogen were found in summer at 1 
$\left(844.0 \mu \mathrm{g} . \mathrm{L}^{-1}\right)$ and the lowest at $16\left(33.6 \mu \mathrm{g} . \mathrm{L}^{-1}\right)$. The highest seasonal mean value was found in winter (235.0 $\left.\mu \mathrm{g} . \mathrm{L}^{-1}\right)$. Esteves et al., (1983) pointed out that the high values of ammonium and nitrate found in some lakes, especially Paulista lake, on the Rio de Janeiro Coast $(1575.5 \mu \mathrm{g} / \mathrm{L}$ and $3.55 \mu \mathrm{g} / \mathrm{L}$ ), indicated that these systems were under heavy human influence.

Degradation of organic matter was one source of phosphorus, along with industrial and domestic waste and run-off from farms (McNeely et al., 1979). The highest total phosphorus values were found at 1 and 2 in Marcelino lake. Input of sewage from the town of Osorio might explain the high values found at these sites.

Total phosphorus concentrations varied between

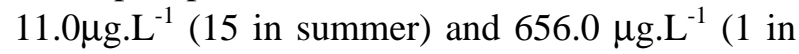
spring). A less evident variability was found in winter, with data ranging from $117.0 \mu \mathrm{g} . \mathrm{L}^{-1}$ at 14 and 15 to $270 \mu \mathrm{g} . \mathrm{L}^{-1}$ at 2 . According to Wetzel (1975), phosphorus concentrations varying from 10.0 to $50.0 \mu \mathrm{g} . \mathrm{L}^{-1}$ were usually found in natural waters. However, concentrations lower than 1 $\mu \mathrm{g} . \mathrm{L}^{-1}$ have been found in natural freshwaters and higher than de $2 \times 10^{5} \mu \mathrm{g} . \mathrm{L}^{-1}$ in saline lakes. Phosphorus can also be taken up by a number of bacteria, which are abundant in the sediment. Turbulence near the sediment may also increase release of phosphorus. Analysis of results showed that the lowest variability in the concentration of this total $\mathrm{P}$ among Peixoto, Pinguela, Palmital, Malvas and Passo lakes occurred in winter, when coefficients of variation were compared between the sampling seasons. Release of phosphorus to the water column was triggered by a number of factors, such as wind action in shallow water bodies, release of nutrients due to degradation of macrophytes and zooplankton waste products (Esteves, 1988) and the action of macro and micro-decomposers on detritus (Wetzel, 1975).

Among the lakes of the northern part of the coast of this state, wind was an important factor for the replacement of phosphorus in the water column, along with selective seasonal storage by aquatic plants. Araújo de Oliveira (1986) registered selective seasonal storage of phosphorus in Patos Lake by Scirpus californicus. In the systems studied here this was also the most abundant macrophyte, which mean that the use of phosphorus by other plants, especially phytoplankton, could be restricted. This could be a life strategy of $S$. californicus in order to ensure its dominance and the possibility of colonising new areas (Araújo de Oliveira, 1986).

Orthophosphate showed a pattern of variation similar to total phosphorus, the highest values being found at 1 and 2 in autumn (393 and 362 $\mu \mathrm{g} . \mathrm{L}^{-1}$ respectively), decreasing progressively at the remaining sites. The lowest values were found in summer (average $29.5 \mu \mathrm{g} . \mathrm{L}^{-1}$ ). Orthophosphate concentrations were low from Pinguela lake to subsequent stations, and in some cases it was not detected. One of the possible explanations was that there may be a fast phosphorus recycling process in the form of orthophosphate (Peters, 1974; Margalef, 1983), rendering it unavailable in the water. Another possibility was the mechanism called "phosphate trap" by Einsele (1938), cited in Fonseca (1991), which involved the precipitation of phosphate species to the sediment, mainly by combination with $\mathrm{Fe}^{3+}$ ions. Fonseca (1991) and Schwarzbold (1982) pointed out the difficulty of typing the lakes of the northern part of the coast of Rio Grande do Sul on the basis of nutrient concentration, mainly due to the high coefficients of variation (monthly, per sampling sites and general). Along with phosphorus and orthophosphate, a water quality gradient was also evident in the $a$ chlorophyll values, with higher concentrations in Marcelino lake. At 1 and 2, the highest values were found. In winter, $a$ chlorophyll concentrations were low, averaging $1.6 \mu \mathrm{g} . \mathrm{L}^{-1}$. In the lakes studied here, the highest average $a$ chlorophyll value $\left(7.1 \mu \mathrm{g} . \mathrm{L}^{-1}\right)$ and also the greatest variability occurred in spring. According to Padilha (2001), a cyanobacterial bloom was observed from 3 site all the way to the canal linking Peixoto to Pinguela lakes, next to 6 . According to Esteves (1988), phytoplankton productivity in tropical lakes, assessed here indirectly through $a$ chlorophyll concentration, depended mainly on the light available in the lake (sub-aquatic radiation) and also on the concentrations of nutrients, especially phosphate, ammonium and nitrate. According to Contreras et al., (1996), the presence of nutrients determined the primary productivity of the system. Usually the relationship was so close that other factors, such as light and $\mathrm{CO}_{2}$, were dismissed as only limiting factors to the process.

In the northern coastal lakes of Rio Grande do Sul, average primary productivity was low and nutrients were not likely to be limiting factors. In this case, light penetration was impaired by the 
excess of suspended and dissolved solids and seemed to be a strong influence determining low production. Bruschi (1998) pointed out that mechanisms such as the immobilization of organic loads by refractory compounds in the sediment seemed to slow down eutrophication processes that occurred through algal blooms and oxygen deficit in the systems studied here.

Classification of lakes by their trophic state is usually based on indices calculated from nutrient content, transparency, phytoplankton and macrophytes, $a$ chlorophyll and lake morphology. Within the morphological classification proposed by Schäfer (1988), Marcelino, Peixoto, Palmital, Malvas and Passo lakes be classified as type 2, i.e. small surface area and shallow. Pinguela lake was type 1 , with a large surface and average depth. The morphological types of the lakes show a wide diversity, with consequences for the balance of substances and ecological and biogeographical characteristics. This is why a classification of these water bodies based on trophic levels is difficult, mainly due to the morphological differences among them.

Usually, the trophic level of a lake can be determined from various trophic indices based on one parameter, or indices combining several variables through mathematical calculations. Bruschi et al. (1998) applied a water-quality index to Marcelino and Peixoto lakes, using physical and chemical variables, and identified low quality water in Marcelino lake and good quality in Peixoto lake. Esteves (1988) pointed out that it was inadequate to apply a classification designed for temperate lakes to tropical ones, since their environmental metabolism was completely different. Thus, the various indicators used $(a$ chlorophyll, transparency, etc) could classify the same system in different categories.

The wind direction and rainfall data were based on Fausto (1999), made available by the Department of Ports, Rivers and Canals (DEPREC). Yearly precipitation in 1997 for the region was $1319 \mathrm{~mm}$. In August and October, rainfall was heaviest, with values as high as $296 \mathrm{~mm}$ and $265 \mathrm{~mm}$. In April, May and July, rainfall was at its lightest, with values of $55 \mathrm{~mm}, 45 \mathrm{~mm}$ and $245 \mathrm{~mm}$, respectively.

Individual analysis of some of the environmental descriptors showed a clear gradient between Marcelino and the remaining lakes. However, estimating the individual importance of each descriptor and its contribution to the characterization of the environment was quite complex, owing to several, mainly spatial, differences. In such cases, Discriminant function analysis was an extremely efficient statistical instrument used (Manly, 1986). According to the Discriminant function coefficients, the variables defining the positioning of samples on the positive end of axis 1 (94.37\% of the variance, table 2) were ammoniacal nitrogen, chlorophyll and nitrite, and on the negative end, turbidity and $\mathrm{BOD}_{5}$, associated to the enrichment caused by sewage input, except turbidity in this specific case, separating the two sites at Marcelino lake from the remaining sites (Fig. 2). Discriminant function 2 explained only $2.2 \%$ of the data variability, separating sites 1 and 2 . This function could be associated with the distance from sewage source since site 1 was located next to the outlet of the sewage treatment works in the town of Osório and site 2 was located further away.

According to principal components analysis, the variables selected as indicators of the gradient in the system were those positioned near the right end hand of the first component (Fig. 3), i. e. the variables with the highest loads in relation to this axis, namely, total nitrogen, $\mathrm{BOD}_{5}, \mathrm{COD}$, total phosphorus and ammonium, directly linked to organic contamination, as well as those reflecting the sequential and not recent effects of this contamination, such as nitrites, nitrates, orthophosphate, chloride, chlorophyll $a$, in addition to magnesium, sodium, potassium, sulphate, alkalinity, hardness and conductivity. The first component reflected the environmental stresses caused mainly by the organic pollution from sewage discharges from the town of Osório into Marcelino lake.

The second component was linked to the variables that were less related to the sewage input, such as water temperature, transparency, $\mathrm{pH}$, organic and inorganic dissolved solids, turbidity and dissolved oxygen. $41.1 \%$ of the variability of the system was explained by axis 1 , and $17.63 \%$ by axis 2 . Only the first component was relevant to the main aim of this analysis, since pollution was already considered an important cause of variability in the environmental data, differences among the lakes having previously been shown. The results appeared to be intimately linked to the disturbance caused by the organic input, reflecting sequential and long-term effects of this modification. Comparing these results to those of Würdig et al., (1990), it was safe to conclude that the water 
quality in the lakes presently studied had decreased in the last few years.

Table 2 - Autovalues, and relative explicability (as percentage) for data distribution. Main statistical parameters for the discriminant analysis performed using physical and chemical data from Marcelino, Peixoto, Pinguela, Palmital, Malvas and do Passo lakes.

\begin{tabular}{|c|c|c|c|c|c|}
\hline $\begin{array}{l}\text { Discrinanting } \\
\text { Function }\end{array}$ & eigenvectors & \multicolumn{2}{|c|}{$\%$ of the variance } & \multicolumn{2}{|c|}{ Canonical Correlation } \\
\hline 1 & 384.1 & \multicolumn{2}{|c|}{94.37} & \multicolumn{2}{|c|}{0.99870} \\
\hline 2 & 8.93 & \multicolumn{2}{|c|}{2.20} & \multicolumn{2}{|c|}{0.94836} \\
\hline 3 & 5.49 & \multicolumn{2}{|c|}{1.35} & \multicolumn{2}{|c|}{0.91981} \\
\hline 4 & 2.21 & \multicolumn{2}{|c|}{0.54} & \multicolumn{2}{|c|}{0.82983} \\
\hline 5 & 1.77 & \multicolumn{2}{|c|}{0.44} & \multicolumn{2}{|c|}{0.79961} \\
\hline \multirow[b]{2}{*}{ Variables } & \multirow[b]{2}{*}{ Function 1} & \multicolumn{4}{|c|}{ Discriminanting function coefficients } \\
\hline & & Function 2 & Function 3 & Function 4 & Function 5 \\
\hline Sech Transparency & -0.42897 & 0.03162 & -0.71677 & -0.36268 & 1.24261 \\
\hline Total Phosphorus & 0.31539 & 0.14766 & 0.28717 & 0.23961 & 0.20121 \\
\hline Depth & 0.02741 & -0.89931 & -1.09113 & -0.18497 & -0.12705 \\
\hline Orthophosphate & 0.16796 & 0.30564 & -0.49892 & 0.38169 & 2.08143 \\
\hline Water Temperature & -0.41033 & -2.66435 & 2.13461 & 0.88933 & 1.31736 \\
\hline Chlorophyl a & 2.83502 & 0.03673 & -0.84826 & 0.08507 & -0.46051 \\
\hline $\mathrm{pH}$ & 0.68959 & 0.00931 & 0.05655 & -0.09999 & 0.31447 \\
\hline Dissolved solids & -0.51890 & 0.24675 & 0.06072 & -0.03474 & 0.19901 \\
\hline Conductivity & 0.27567 & 0.13412 & 0.72470 & -0.16275 & -2.08226 \\
\hline Organic Susp. Solids & -0.15878 & 0.05778 & 0.55807 & -1.09537 & 0.43154 \\
\hline Alkalinity & -0.13978 & 0.36225 & -0.16436 & -0.00148 & 0.09304 \\
\hline Inorganic Susp. Solids & -0.32465 & 0.65219 & 0.80822 & 0.30523 & -0.32662 \\
\hline Sulphate & 0.30216 & 0.45382 & -0.27301 & 0.53697 & 0.91782 \\
\hline Hardness & 0.56833 & 0.44880 & 0.21843 & -0.48392 & -1.12042 \\
\hline Chloride & 0.61610 & -0.45445 & -0.35909 & 0.18706 & 1.51276 \\
\hline Turbidity & -1.28701 & -2.72008 & 0.70341 & 1.11410 & -0.64937 \\
\hline COD & -0.28092 & -0.22288 & -0.18537 & 1.22841 & 0.02112 \\
\hline Calcium & 0.28484 & 0.03977 & -1.04764 & 0.43615 & 1.30879 \\
\hline Dissolved oxygen & 0.03581 & -0.66535 & 0.73073 & -0.92146 & 1.48069 \\
\hline Magnesium & -0.63287 & 0.16267 & -0.15518 & -0.49078 & 0.78602 \\
\hline BOD & -0.85308 & 0.89068 & -0.18626 & 0.20290 & -0.61217 \\
\hline Sodium & 0.07201 & -0.07272 & -0.34839 & 0.28902 & -0.22628 \\
\hline Total Nitrogen & 0.49929 & 0.27975 & -0.04420 & -0.43829 & -1.05435 \\
\hline Potassium & 0.37839 & -0.12192 & -0.41669 & 0.18932 & -0.10033 \\
\hline Amoniacal Nitrogen & 3.39485 & -1.96746 & 0.75843 & -0.91956 & 0.13625 \\
\hline Nitrite & 1.71542 & -0.46182 & 0.25693 & 0.06159 & -0.04644 \\
\hline Nitrate & -0.13067 & -0.14627 & 0.21135 & 0.46394 & -0.21945 \\
\hline
\end{tabular}




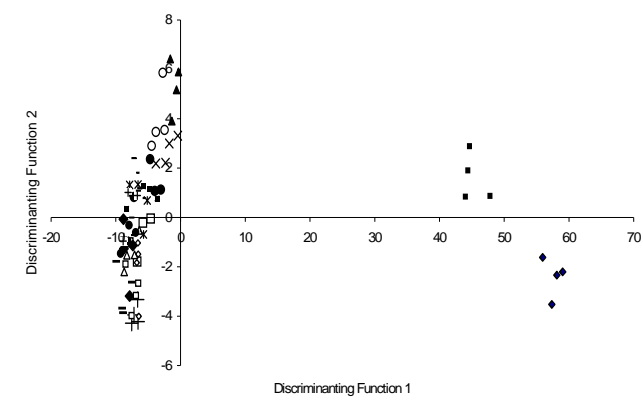

•1 • $2 \Delta 3 \times 405 \bullet 6+7 \square 8-9 \bullet 10 \square 11 \Delta 12 \cdot 13 * 14 \bullet 15+16 \cdot 17-18 \bullet 19$

Figure 2 - Discriminant analisys applied to physical and chemical variables, at 19 sampling sites in Marcelino, Peixoto, Pinguela, Palmital, Malvas and Do Passo lakes.

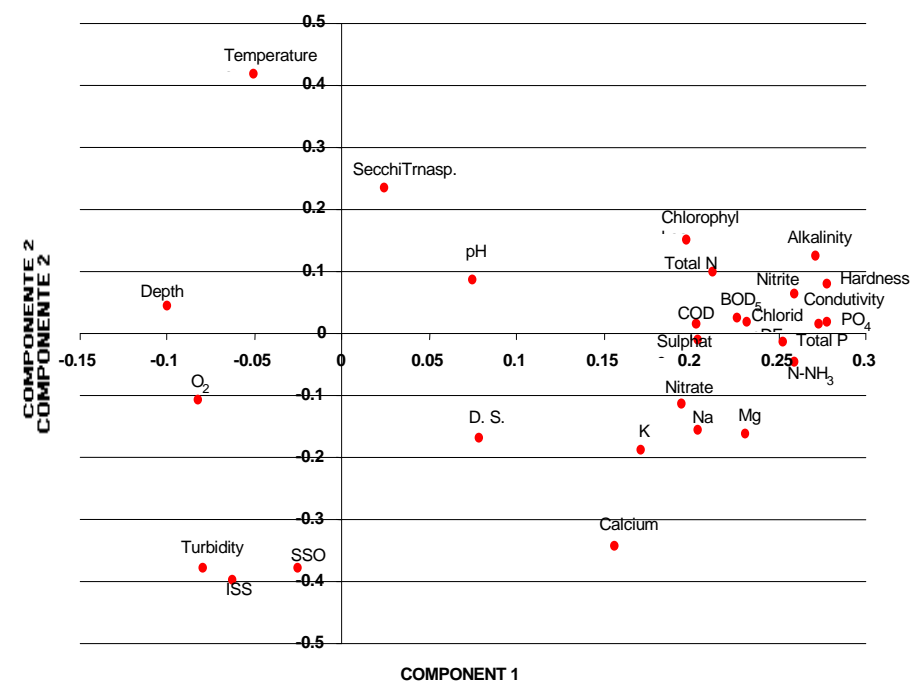

Figure 3 - Distribuition of eigenvectors resulting from Principal Component Analysis applied to Physical and chemical parameters measured in Marcelino, Peixoto, Pinguela, Palmital, Malvas and Do Passo Lakes.

\section{CONCLUSIONS}

Knowledge of the main characteristics of the complex of lakes studied here could be useful in directing community efforts towards their preservation and the exploitation of the resources without harm to the environment. It is important to emphasize the differences found concerning functional processes in the lake system studied. Marcelino lake received the continuous input of organic matter from the sewage treatment Osório, whereas Peixoto, Pinguela, Palmital, Malvas and Do Passo lakes resembled other water bodies described in the region, not showing so far signs of degradation caused by the human occupation of the surrounding land and the resulting input of effluents.

The existence of a gradient of physical, chemical and biological characteristics through the lakes was confirmed. The sequence was as follows: Marcelino, Peixoto, Pinguela, Palmital, Malvas and Do Passo lakes. This gradient was 
characterised generally by a decrease in nutrient and ion concentration, conductivity, hardness, alkalinity, COD, BOD and chlorophyll and by a slight increase in dissolved oxygen and dissolved solids. Turbidity and water transparency reflected the influence of winds on the system, the water in the larger systems being more turbid and in the smaller ones, more transparent. Total nitrogen, $\mathrm{BOD}_{5}, \mathrm{COD}$, total phosphorus and ammoniacal nitrogen were the environmental descriptors which showed more clearly the alterations caused by the input of sewage into the system, especially in the warmer months, while nitrite, nitrate, orthophosphate, chloride, a chlorophyll, magnesium, sodium, potassium, sulphide, alkalinity and conductivity, reflected the sequential and long-term effects of this contamination.

\section{RESUMO}

O propósito do presente estudo foi avaliar a qualidade ambiental das lagoas Marcelino, Pinguela, Peixoto, Palmital, Malvas e Lagoa do Passo, ecossistemas interligados nesta seqüência por canais e localizados próximos a cidade de Osório, Rio Grande do Sul. Foram analisadas vinte e nove variáveis ambientais físicas e químicas no período de janeiro, maio, julho e outubro de 1997. Constatou-se, através de uma análise de discriminantes canônicos utilizando-se as variáveis ambientais, que as lagoas apresentaram características limnológicas diferenciadas em função do aporte dos efluentes urbanos: a lagoa Marcelino mostrou contaminação orgânica e foi separada das demais lagoas evidenciando um gradiente de qualidade ambiental. Posteriormente, uma análise de componentes principais diferenciou as estações amostrais selecionando descritores ambientais ligados diretamente com a contaminação orgânica e outros que refletem os efeitos seqüenciais e não recentes desta contaminação.

\section{REFERENCES}

APHA 1995. American Public Health Association. Standard Methods for the examination of water and wastewater. $19^{\text {th }}$ ed .Washington, DC.: APHA. 982pp.

Araújo De Oliveira, M. E. (1986), Avaliação sazonal do conteúdo de $\mathrm{P}_{-} \mathrm{PO}_{4}$, biomassa e densidade em Scirpus californicus, no Saco de Tapes (RS). Acta Limnol.Brasil., São Carlos, SP., 1:299-316.

Bruschi JR., W.; Salomoni, S. E; Fermino, F. S.; Pedrozo, C. DA S.; Schwarzbold, A.; Peret, A. C. (1998), Aplicação de um índice de qualidade de águas para lagoas costeiras, RS, afetadas por despejos urbanos. Biociências, 6(1):55-66.

Bruschi JR., W. (1998). Influência de despejos urbanos sobre a ictiofauna das lagoas costeiras Marcelino e Peixoto, Osório, RS, Brasil. PhD Thesis, UFSCar, São Carlos, Brazil.

Camargo, A. F. M.; Niyai, R. K. (1988), Caracterização limnológica do Lago Curuça: Lado da Várzea do Rio Trombetas (águas claras), Pará. Acta Limnologica Brasiliensia, São Paulo, 2:153-180.

Cardoso, L. de S. (2001), Variações da estrutura planctônica da Lagoa Itapeva (Sistema Lagunar Costeiro do Rio Grande do Sul) em função da hidrodinâmica. PhD Thesis, UFRGS, Porto Alegre, Brazil.

Cardoso, L. de S.; Marques, D. da M. (2004), The influence of Hydrodynamics on the spacial and temporal variation of phytoplankton pigments in a large, sub-tropical coastal lake (Brazil). Brazilian Archives of Biology and Technology, 47(4): 587-600.

Contreras, F., Castañeda, L., Torres-Alvarado, R. Gutiérrez F. (1996), Nutrientes em 39 lagunas costeras mexicanas. Rev. Biol. Trop., 44(2): 417-425.

Esteves, F.A., Barbieri, R., Ishii, I.H. (1983), Estudos Limnológicos em algumas lagoas costeiras do Estado do Rio de Janeiro. Paper presented at $2^{\text {th }}$ Semana Regional de Ecologia, São Carlos, São Paulo.

Esteves, F.A. (1988), Fundamentos de Limnologia. Interciência - FINEP, Rio de Janeiro.

Fausto, I.V. (1999), Abundância sazonal do camarãorosa Farfantepenaeus paulensis na Laguna Tramandaí, RS, Brasil (Crustacea, Decapoda, Penaeidae). MSc Thesis, PUC, Porto Alegre, Brazil.

Fepam. (2000). Diretrizes Ambientais para o Desenvolvimento dos Municípios do Litoral Norte. Cadernos de Planejamento e Gestão Ambiental, No. 1, Porto Alegre.

Fonseca, O.J.M. (1989), Física e química das águas de oito lagoas costeiras do Rio Grande do Sul. UFRGS, Porto Alegre, (Technical Report).

Fonseca, O.J.M. (1991), Aspectos Limnológicos da Lagoa Emboaba, Planície Costeira Setentrional do Rio Grande do Sul: morfometria , hidroquímica e degradação de Scirpus californicus (C.A. Meyer) Steud. PhD Thesis, UFSCar, São Carlos, Brazil. 
Golterman, H.L., Clymo, R.S., Ohnstad, M.A.M. (1978), Methods for physical and chemical analysis of freshwater. Blackwell Scientific Pubs. Oxford.

Hasenack, H., Ferraro, L.W. (1989), Considerações sobre o clima da região de Tramandaí, RS. Pesquisas, 22:53-70.

Kirk, J.T.O. (1983), Light and photosynthesis in aquatic ecosystems. Cambridge: University Press.

Kleerekoper, H. (1990), Introdução ao Estudo da Limnologia. $2^{\text {a }}$ Ed. Da Universidade, UFRGS, Porto Alegre.

Machado, N.A.F. (2001) Planejamento ambiental aplicado às lagoas costeiras da bacia do Rio Tramandaí. PhD Thesis, UFSCar, São Carlos, Brazil.

Manly, B.F.J. (1986), Multivariate statistical methods: A primer. Chapman and Hall ltd. Londres.

Margalef, R. (1983), Limnologia. Omega, Barcelona.

Mcneely, R.N., Neimasis, V.P., Dwyer, L. (1979), Oxigen-chemical oxygen demand. In: Water Quality Sourcebook. A guide to water quality parameters. Water Quality Branch Inland Waters Directorate, Environment Canadá, Ottawa, p.32-33.

Moreno, J.A. (1961), Clima do Rio Grande do Sul. Secretaria da Agricultura. Porto Alegre, Rs, Brazil.

Padilha, R. dos Santos, (2001), Contribuição à tipologia de lagoas costeiras do litoral norte do Rio Grande do Sul, com ênfase na comunidade fitoplanctônica. MSc Thesis, UFRGS, Porto Alegre, Brazil.

Peters, R.H. (1974), Orthophosphate turnover in central European Lakes. Mem. Ist. Ital. Idrobiol., Milano, 32:297-311.

Schäfer, A. (1988), Tipificação ecológica das lagoas costeiras do Rio Grande do Sul, Brasil. Acta Limnol. Brasiliensia, II:29-55.

Schäfer, A. (1990), Avaliação do impacto ambiental nas lagoas Marcelino, Peixoto e Pinguela, baseada em levantamentos físicos e químicos. In: Würdig, N.L. et al. (Coordenadora), Bases ecológicas para medidas de saneamento das lagoas Marcelino, Peixoto e Pinguela, município de osório, RS. UFRGS, Porto Alegre, (Technical Report).
Schäfer, A. (1992), Ecological characteristics of the coastal lakes in Southern Brazil: a synthesis. Acta Limnol. Brasiliensia, IV:111-122.

Schwarzbold, A., Schäfer, A. (1984), Gênese e morfologia das lagoas costeiras do Rio Grande do Sul - Brasil. Amazoniana, IX,(1):87-104.

Schwarzbold, A. (1982), Influência da morfologia no balanço de substâncias e na distribuição de macrófitas aquáticas nas lagoas costeiras do Rio Grande do Sul. MSc Thesis, UFRGS, Porto Alegre, Brazil.

Stratigrafics 6.0 (1986) User's Guide. [s.1.]: Statistical Graphics Corporation. 3v.

Tabajara, L.L.C. (1994), Aspectos hidrodinâmicos e sedimentologia do sistema lagunar-estuarino de Tramandaí-RS. PhD Thesis, UFRGS, Porto Alegre, Brazil.

Tomazelli, L.J., Willwock, J.A. (1991), Geologia do sistema lagunar holocênico do litoral norte do Rio Grande do Sul, Brasil. Pesquisas, 18 (1)13-24.

Wetzel, R.G. (1975), Limnology. W.B. Saunders Co., Philadelphia.

Würdig, N.L. (1984), Ostracodes do Sistema Lagunar de Tramandaí, RS, Brasil. Sistemática Ecologia e Subsídios a Paleoecologia. MSc Thesis, UFRGS, Porto Alegre, Brazil.

Würdig, N.L., Schäfer, A., Machado, N.A.F., Lanzer, R., Freitas, S.F., Fausto, I. (1990), V. Bases ecológicas para medidas de saneamento das lagoas Marcelino, Peixoto e Pinguela, município de Osório, RS. UFRGS, Porto Alegre (Technical Report).

Received: July 14, 2005; Revised: May 08, 2006; Accepted: March 06, 2007. 
PÁGINA

EM

BRANCO 